\title{
СИНТЕЗ И ИССЛЕДОВАНИЕ НОВЫХ АЦИКЛИЧЕСКИХ СТРУКТУРНЫХ АНАЛОГОВ 3-ФЕНАЦИЛУРИДИНА
}

\author{
О.В. Вострикова', И.А. Новаков', М.Б. Навроцкий', И.А. Кириллов', \\ Е.С. Титова', Т.Г. Толстикова ${ }^{2}$ \\ ${ }^{1}$ ФГБОУ ВО Волгоградский государственный технический университет, \\ 400005, Российская Федерация, Волгоград, пр. имени Ленина, 28. \\ ${ }^{2}$ Новосибирский институт органической химии им. Н. Н. Ворожцова СО РАН, \\ 630090, Россия, г. Новосибирск, пр. Академика Лаврентьева, 9.
}

DOI: 10.19163/MedChemRussia2021-2021-235

E-mail: olyavostrikova@yandex.ru

Поиск новых снотворных средств, лишенных способности вызывать привыкание и болезненное пристрастие, продолжает оставаться одним из важных направлений химии лекарств на сегодняшний день. Ранее было показано, что $N^{3}$-фенацилуридин обладает выраженной снотворной активностьюпри интрацеребеллярном введении в опытах invivo [1]. В этой связи, нами были предложены к синтезу, получены и исследованы в опытах invivo уксусные эфиры биоизостерических аналогов 3-фенацилуридина, содержащие ациклонуклеозидный остаток в положении 1 пиримидинового гетероциклаи обладающие большей липофильностью по сравнению с прототипом [2].

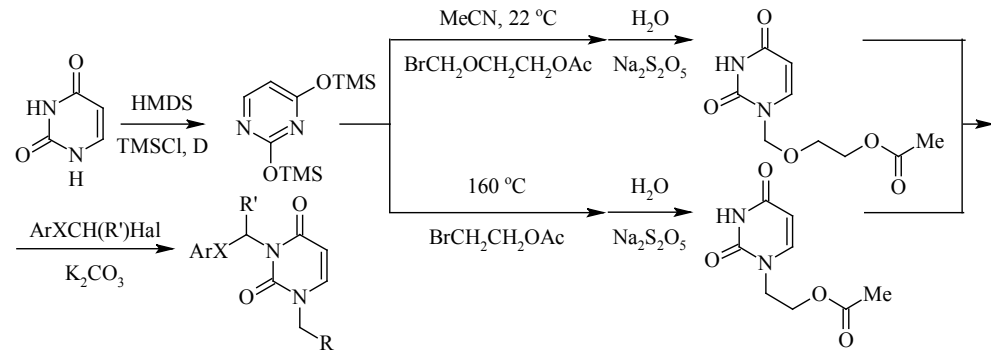

где $R=\mathrm{AcOCH}_{2} \mathrm{CH}_{2} \mathrm{O}, \mathrm{AcOCH}{ }_{2} ; \mathrm{R}^{\prime}=\mathrm{H}, \mathrm{Me} ; \mathrm{X}=\mathrm{C}(\mathrm{O}), \mathrm{S} ; \mathrm{Ar}=\mathrm{Ph}, 4-\mathrm{MeOC}_{6} \mathrm{H}_{4}, 4-\mathrm{FC}_{6} \mathrm{H}_{4}$

Структура и чистота полученных соединений доказаны с использованием современных физико-химических методов анализа. Изучение биологических свойств этих веществ в условиях острого эксперимента invivo не выявило наличия у них собственных гипнотических свойств и способности усиливать эффекты хлоралгидрата и диазепама.

\section{Литература}

[1]. I. Yamamoto, J. Kuze, T. Kimura, K. Watanabe, S. Kondo, I. K. Ho. The Potent Depressant Effects of N3-Phenacyluridine in Mice // Biological and Pharmaceutical Bulletin. 1994. - Vol. 17, No. 4. - P. 514-516.

[2]. И. А. Новаков, Л. Л. Брунилина, И. А. Кириллов, М. Б. Навроцкий, М. Д. Робинович, Е. С. Титова, Д. С. Шейкин, Е.А. Ручко, А. В. Павлова, А. А. Котлярова, Т. Г. Толстикова. Синтез новых ациклических аналогов 3-фенацилуридина и сравнительная оценка их биологической активности invivo // Химия гетероциклических соединений. - 2020. - Т. 56, № 6. - С. 769-775. 